Swarthmore College

Works

\title{
Use Of Culture-Independent Methods To Compare Bacterial Assemblages On Feathers Of Crested And Least Auklets (Aethia Cristatella And Aethia Pusilla) With Those Of Passerines
}

\author{
M. D. Shawkey \\ M. Jawaad Hussain , '09 \\ Aaron Leigh Strong , '06 \\ J. Hagelin \\ Amy Cheng Vollmer \\ Swarthmore College, avollme1@swarthmore.edu
}

See next page for additional authors

Follow this and additional works at: https://works.swarthmore.edu/fac-biology

Part of the Biology Commons, and the Microbiology Commons

Let us know how access to these works benefits you

\section{Recommended Citation}

M. D. Shawkey; M. Jawaad Hussain , '09; Aaron Leigh Strong , '06; J. Hagelin; Amy Cheng Vollmer; and G. E. Hill. (2006). "Use Of Culture-Independent Methods To Compare Bacterial Assemblages On Feathers Of Crested And Least Auklets (Aethia Cristatella And Aethia Pusilla) With Those Of Passerines". Waterbirds. Volume 29, Issue 4. 507-511. DOI: 10.1675/1524-4695(2006)29[507:UOCMTC]2.0.CO;2 https://works.swarthmore.edu/fac-biology/74

This work is brought to you for free by Swarthmore College Libraries' Works. It has been accepted for inclusion in Biology Faculty Works by an authorized administrator of Works. For more information, please contact myworks@swarthmore.edu. 


\section{Authors}

M. D. Shawkey; M. Jawaad Hussain , '09; Aaron Leigh Strong , '06; J. Hagelin; Amy Cheng Vollmer; and G.

E. Hill 


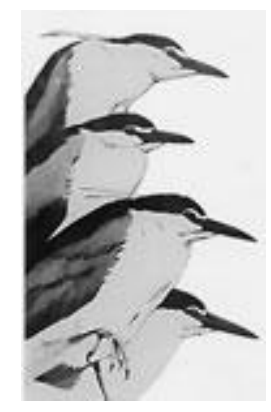

Use of Culture-Independent Methods to Compare Bacterial Assemblages on Feathers of Crested and Least Auklets (Aethia cristatella and Aethia pusilla) with Those of Passerines Author(s): Matthew D. Shawkey, M. Jawaad Hussain, Aaron L. Strong, Julie C. Hagelin, Amy C. Vollmer and Geoffrey E. Hill

Source: Waterbirds: The International Journal of Waterbird Biology, Vol. 29, No. 4 (Dec., 2006), pp. 507-511

Published by: Waterbird Society

Stable URL: http://www.jstor.org/stable/4132513

Accessed: 27-10-2017 13:31 UTC

\section{REFERENCES}

Linked references are available on JSTOR for this article: http://www.jstor.org/stable/4132513?seq=1\&cid=pdf-reference\#references_tab_contents You may need to $\log$ in to JSTOR to access the linked references.

JSTOR is a not-for-profit service that helps scholars, researchers, and students discover, use, and build upon a wide range of content in a trusted digital archive. We use information technology and tools to increase productivity and facilitate new forms of scholarship. For more information about JSTOR, please contact support@jstor.org.

Your use of the JSTOR archive indicates your acceptance of the Terms \& Conditions of Use, available at http://about.jstor.org/terms

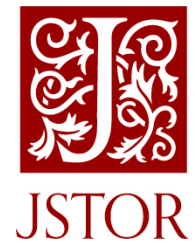

Waterbird Society is collaborating with JSTOR to digitize, preserve and extend access to Waterbirds: The International Journal of Waterbird Biology 


\title{
Use of Culture-Independent Methods to Compare Bacterial Assemblages on Feathers of Crested and Least Auklets (Aethia cristatella and Aethia pusilla) with Those of Passerines
}

\author{
MatThew D. ShawkeY ${ }^{*}$, M. JaWAad HuSSAin ${ }^{2}$, Aaron L. Strong ${ }^{2}$, \\ Julie C. HAGElin ${ }^{2}$, AMY C. VOLLMER ${ }^{2}$ AND GEOFFReY E. Hill ${ }^{1}$ \\ ${ }^{1}$ Department of Biological Sciences, 331 Funchess Hall, Auburn University, Auburn, AL 36849, USA \\ ${ }^{2}$ Department of Biology, Swarthmore College, 500 College Avenue, Swarthmore, PA 19081-1397, USA
*Present address: Department of Environmental Science, Policy and Management, Ecosystem Science Division 137 Mulford Hall \#3114, University of California, Berkeley, CA 94720-311, USA
Internet: mshawkey@nature.berkeley.edu

\begin{abstract}
Despite recent interest in the interactions between birds and feather microbes, little is known about the identity of these microbes, and all studies of feather microbes thus far have focused on passerines living in temperate regions. Comparisons of the microbial groups living on different groups of birds may provide valuable insight into the ecological roles microbes play on feathers. We used culture-independent molecular techniques to identify the assemblages of bacteria found on the feathers of two closely related seabirds (Crested and Least Auklets (Aethia cristatella and A. pusilla)) and, for comparison, domestic Chickens (Gallus gallus). Some isolates were found on all three species (as well as on other species, as reported in the literature), while others were only found on Auklets. In particular, bacteria of the cold- and salt-tolerant genus Psychrobacter were only recovered from Crested Auklets. These results suggest that some genera of bacteria may be commonly found on birds, while others may be restricted in their distributions. Received 25 March 2006, accepted 21 June 2006.
\end{abstract}

Key words.-feather microbes, culture-independent, seabirds, $16 \mathrm{~S}$ rDNA, Auklets, keratinolytic.

Waterbirds 29(4): 507-511, 2006

The potential interactions between birds and the microbes on their feathers have received significant attention recently (Burtt and Ichida 1999; Shawkey et al. 2003; Goldstein et al. 2004; Shawkey and Hill 2004; Lucas et al. 2005; Shawkey et al. 2005). Several of these studies have focused on bacteria that are capable of degrading keratin (Burtt et al. 1999; Goldstein et al. 2004; Shawkey et al. 2003), while others have focused on entire bacterial assemblages (Lucas et al. 2005; Shawkey et al. 2003, 2005). These assemblages appear to be fairly diverse; Shawkey et al. (2005) recovered 20 unique bacterial isolates from feathers of Eastern Bluebirds (Sialia sialis) and 13 from House Finches (Carpodacus mexicanus) in a less-intensive survey (Shawkey et al. 2003). Until now, these studies have been entirely restricted to passerines. By examining the composition of assemblages on other groups of birds, we may improve our understanding of the diversity of bacteria associated with bird feathers. Seabirds differ from passerines in habitat, morphology and physiology; thus, we might ex- pect their bacterial assemblages to differ as well. For example, we would expect to find salt-tolerant bacteria on these birds that spend much of their time in the ocean water.

Crested (Aethia cristatella) and Least (A. pusilla) Auklets are arctic seabirds that breed in mixed colonies on islands and coastlines around the Bering Sea and winter in flocks on nearby waters (Jones 1993a, b). The microbial assemblages found on the feathers of these or any other seabird have never been studied. Here we use culture-independent techniques to characterize bacteria found on feathers of Crested and Least Auklets and, for comparison, domestic Chickens (Gallus gallus). We expected the assemblages on Crested and Least Auklet feathers to be similar to one another and distinct from those on feathers of Chickens and passerines.

\section{METHODS}

Crested and Least Auklets were captured using carpet traps on St. Lawrence Island, Alaska $\left(63.69^{\circ} \mathrm{N}, 170.48^{\circ} \mathrm{W}\right)$ in August, 2004. Birds were handled with sterile gloves, 
and approximately 25 feathers were pulled from the rump and nape of each bird. These feathers were placed in sterile $15 \mathrm{ml}$ plastic tubes (Falcon, city) and stored at $20^{\circ} \mathrm{C}$ until being shipped on ice to Swarthmore College, where they were stored at $4^{\circ} \mathrm{C}$ until the time of analysis. Single wing feathers (primaries) were collected from labreared chicks at Swarthmore College and stored in sterile tubes at $4^{\circ} \mathrm{C}$ until the time of analysis.

Feathers were placed at room temperature overnight, and then homogenized in liquid nitrogen using a sterile mortar and pestle. The homogenate was then resuspended in $10 \mathrm{ml}$ buffer solution $(0.85 \% \mathrm{NaCl}$, $1 \mathrm{mM}$ EDTA, $20 \mathrm{mM}$ Tris-HCl, $\mathrm{pH} 8.0$ ) and immediately processed or frozen at $-20^{\circ} \mathrm{C}$. To loosen bacteria, homogenates were shaken at room temperature at $200 \mathrm{rpm}$ for 20 minutes, and then $1 \mathrm{ml}$ aliquots were centrifuged at $17,000 \mathrm{~g}$ for 10 minutes. DNA was extracted from pellets using the DNeasy tissue extraction kit (Qiagen, Valencia, California) according to the manufacturers' recommendations for gram-positive bacteria.

PCR amplification of $16 \mathrm{~S}$ rDNA signature sequences and subsequent cloning were performed following the methods of Shawkey et al. (2005). Following cloning, colonies containing inserts were picked and grown overnight with agitation at $37^{\circ} \mathrm{C}$ in LB broth with $50 \mu \mathrm{g} / \mathrm{ml}$ kanamycin. Aliquots $(1 \mathrm{ml})$ of cultures were centrifuged at 10,000 rpm for five minutes and plasmids were purified from pellets using the QIAprep MiniPrep kit for plasmids (Qiagen, Valencia, Californai) according to the manufacturers' recommendations. Plasmids were then amplified by PCR using the vector primers M13F and $\mathrm{M} 13 \mathrm{R}$ in $100 \mu \mathrm{l}$ reaction volumes containing $\sim 25 \mathrm{ng}$ DNA, $1 \times$ PCR buffer, $200 \mu \mathrm{M}$ dNTP's, $400 \mu \mathrm{M}$ of each forward and reverse primer, and $0.025 \mathrm{U} / \mu \mathrm{l}$ recombinant Taq polymerase (Invitrogen, Carlsbad, California). The PCR consisted of an initial denaturing step $\left(94^{\circ} \mathrm{C}\right.$, $10 \mathrm{~min})$, followed by 36 cycles of denaturation $\left(94^{\circ} \mathrm{C}\right.$, $1 \mathrm{~min})$, annealing $\left(50^{\circ} \mathrm{C}, 1 \mathrm{~min}\right)$ and extension $\left(72^{\circ} \mathrm{C}\right.$, $2 \mathrm{~min})$, and a final extension step $\left(72^{\circ} \mathrm{C}, 10 \mathrm{~min}\right)$.

\section{RFLP Screening of rDNA Clones}

To minimize sequencing of redundant clones were screened using a restriction fragment length polymorphism (RFLP) analysis. Aliquots $(10 \mu \mathrm{l})$ of crude PCR product were digested to completion with $1 \mathrm{U}$ each of restriction enzymes MspI and HinP1 I in $1 \times$ NEB buffer 2 (New England Biolabs, Beverly, Massechusetts) in a final volume of $20 \mu \mathrm{l}$ for at least one hour at $37^{\circ} \mathrm{C}$. Digested products were separated on agarose gels (4\% MetaPhor ${ }^{\circledR}$, Cambrex, Baltimore, Maryland). PCR products with unique RFLP patterns were selected for sequencing. Unique products were purified using the QIAquick PCR Purification kit (Qiagen, Valencia, California) and sequenced at the Nucleic Acid/Protein Research Core Facility at Children's Hospital of Philadelphia.

Sequences were inspected manually for the presence of ambiguous base assignments. The Bellerophon program (Huber et al. 2004) was used to detect potentially chimeric sequences, and the Chimera Check program in the Ribosomal Database Project (Maidak et al. 1997) was used for verification. The BLAST algorithm was (Altschul et al. 1997) used to determine their approximate phylogenetic affiliation. All chimeric sequences and sequences with $>99 \%$ similarity to known PCR contaminants (Tanner et al. 1998) were discarded. Sequences that were $\geq 99 \%$ similar to one another were considered as a single relatedness group.

\section{RESULTS}

Nape feathers of two Least Auklets and two Crested Auklets, rump feathers of two Least Auklets and one Crested Auklet and wing feathers of eight domestic chicks were analyzed. Approximately 10 clones from each library were screened using RFLP for a total of 150 clones. A total of 47 unique patterns were detected.

The BLAST program identified 28 different 16S rDNA gene sequences as the closest relatives of the feather bacteria sequences (Table 1). Approximately $63 \%$ of the unique sequences obtained were between 98 and $100 \%$ identical to their closest matches in GenBank, and approximately $37 \%$ of the sequences obtained were between 95 and $97 \%$ identical to their nearest match. One sequence was identified as a chimera and was discarded.

All recovered sequences were most closely related to members of the Firmicutes and Proteobacteria (Table 1). The largest number of unique sequences was recovered from nape feathers of Crested Auklets (8), followed by wing feathers of domestic Chickens (7), Least Auklet nape feathers (6), Crested Auklet rump feathers (4) and Least Auklet rump feathers (3). Isolates closely related to Janthinobacterium spp. were recovered from nape feathers of Crested and Least Auklets, while isolates closely related to Burkholderia spp. were recovered from Chicken wing feathers, Crested Auklet rump feathers and Least Auklet nape feathers. Isolates closely related to Staphylococcus spp. were recovered from both Chicken wing feathers and Least Auklet rump feathers.

\section{DISCUSSION}

Fairly diverse groups of bacteria were isolated from feathers of Crested and Least Auklets. Comparison of these isolates with those from domestic Chickens, Eastern Bluebirds (Shawkey et al. 2005) and House Finches (Shawkey et al. 2003) allowed identification of potential Auklet or arctic seabird specialists. Many genera of isolates from Auklets were also found either on Chickens, bluebirds or House Finches (see Table 1), suggesting that they are commonly distributed 
Table 1. Identification of clones from culture-independent survey of feathers from domestic Chickens and Crested and Least Auklets. The bacterial species in GenBank with the closest DNA sequence to each isolate (as determined by the BLAST algorithm) is presented as a preliminary identification. Whether members of each genus have been found on bluebirds (as reported in Shawkey et al. 2005) and/or House Finches (as reported in Shawkey et al. 2003) is noted in the column labeled "Also found on."

\begin{tabular}{|c|c|c|c|c|c|c|}
\hline Sample & Species & Feather & $\begin{array}{c}\text { Highest } \\
\text { BLAST identity } \\
\text { (Accession \#) }\end{array}$ & $\begin{array}{c}\text { Also } \\
\text { found on }\end{array}$ & Division & $\begin{array}{l}\text { Base pairs } \\
\text { matched }\end{array}$ \\
\hline Chick 1B & Chicken & wing & $\begin{array}{l}\text { Shigella boydii } \\
\text { (AY696681) }\end{array}$ & & $\gamma$-proteobacteria & $477 / 479(99 \%)$ \\
\hline Chick 2D & Chicken & wing & $\begin{array}{l}\text { Escherichia coli } \\
\text { (AE005174) }\end{array}$ & & $\gamma$-proteobacteria & $823 / 831(99 \%)$ \\
\hline Chick 3A-1 & Chicken & wing & $\begin{array}{l}\text { Staphylococcus sp. } \\
\text { (AM084016) }\end{array}$ & House finch & Firmicutes & $851 / 864(98 \%)$ \\
\hline Chick 4A-1 & Chicken & wing & $\begin{array}{l}\text { Enterococcus canintestini } \\
\text { (AJ888906) }\end{array}$ & $\begin{array}{l}\text { House finch, } \\
\text { bluebird }\end{array}$ & Firmicutes & $863 / 870(99 \%)$ \\
\hline Chick 4C-1 & Chicken & wing & $\begin{array}{l}\text { Enterococcus gallinarum } \\
\text { (AF277567) }\end{array}$ & $\begin{array}{l}\text { House finch, } \\
\text { bluebird }\end{array}$ & Firmicutes & $699 / 713(98 \%)$ \\
\hline Chick 5A-2 & Chicken & wing & $\begin{array}{l}\text { Enterococcus faecium } \\
\text { (AY735408) }\end{array}$ & $\begin{array}{l}\text { House finch, } \\
\text { bluebird }\end{array}$ & Firmicutes & $842 / 845(99 \%)$ \\
\hline Chick 5E & Chicken & wing & $\begin{array}{l}\text { Burkholderia sp. } \\
\text { (AY040359) }\end{array}$ & & $\beta$-proteobacteria & $545 / 548(99 \%)$ \\
\hline CR62N-1 & Grested Auklet & nape & $\begin{array}{l}\text { Bacillus subtilis } \\
\text { (AY775778) }\end{array}$ & $\begin{array}{l}\text { House finch, } \\
\text { bluebird }\end{array}$ & Firmicutes & 987/994 (99\%) \\
\hline CR67B & Crested Auklet & nape & $\begin{array}{l}\text { Psychrobacter luti } \\
\text { (AJ430828) }\end{array}$ & & $\gamma$-proteobacteria & $852 / 871(97 \%)$ \\
\hline CR7C-2 & Crested Auklet & nape & $\begin{array}{l}\text { Psychrobacter fozii } \\
\text { (AY771717) }\end{array}$ & & $\gamma$-proteobacteria & $814 / 821(99 \%)$ \\
\hline AUBURN-3 & Crested Auklet & nape & $\begin{array}{l}\text { Pseudomonas sp. } \\
\text { (AY69069) }\end{array}$ & $\begin{array}{l}\text { House finch, } \\
\text { bluebird }\end{array}$ & Proteobacteria & $732 / 750(97 \%)$ \\
\hline AUBURN-5 & Crested Auklet & nape & $\begin{array}{l}\text { Aeromonas sp. } \\
\text { (ASU88662) }\end{array}$ & bluebird & $\gamma$-proteobacteria & $676 / 696(97 \%)$ \\
\hline AUBURN-1 & Crested Auklet & nape & $\begin{array}{l}\text { Janthinobacterium sp. } \\
\text { (AJ864846) }\end{array}$ & bluebird & $\beta$-proteobacteria & $694 / 728(95 \%)$ \\
\hline AUBURN-7 & Crested Auklet & nape & $\begin{array}{l}\text { Janthinobacterium livi- } \\
\text { dum (JL16SRRN) }\end{array}$ & bluebird & $\beta$-proteobacteria & $760 / 776(97 \%)$ \\
\hline AUBURN-9 & Crested Auklet & nape & $\begin{array}{l}\text { Stenotrophomonas malto- } \\
\text { philia (AY169434) }\end{array}$ & bluebird & $\gamma$-proteobacteria & $775 / 801(96 \%)$ \\
\hline CR50R-3 & Crested Auklet & rump & $\begin{array}{l}\text { Burkholderia sp. } \\
\text { (AF452132) }\end{array}$ & & $\beta$-proteobacteria & $950 / 987(96 \%)$ \\
\hline CR50R-4 & Crested Auklet & rump & $\begin{array}{l}\text { Acinetobacter sp. } \\
\text { (AY663435) }\end{array}$ & bluebird & $\gamma$-proteobacteria & $647 / 649(99 \%)$ \\
\hline CR50R-5 & Crested Auklet & rump & $\begin{array}{l}\text { Acinetobacter sp. } \\
\text { (ASI6SRRNB) }\end{array}$ & bluebird & $\gamma$-proteobacteria & $978 / 979(99 \%)$ \\
\hline CR50R-6 & Crested Auklet & rump & $\begin{array}{l}\text { Acinetobacter sp. } \\
(\mathrm{AB} 167212)\end{array}$ & bluebird & $\gamma$-proteobacteria & $956 / 957(99 \%)$ \\
\hline LE53R-6 & Least Auklet & rump & $\begin{array}{l}\text { Paenibacillus dendriti- } \\
\text { formis (AY359885) }\end{array}$ & & Firmicutes & $802 / 810(99 \%)$ \\
\hline LE53R-7 & Least Auklet & rump & $\begin{array}{l}\text { Paenibacillus thiami- } \\
\text { nolyticus (AB073197) }\end{array}$ & & Firmicutes & $828 / 834(99 \%)$ \\
\hline LE55R-1 & Least Auklet & rump & $\begin{array}{l}\text { Staphylococcus equorum } \\
\text { (DQ232735) }\end{array}$ & House finch & $\gamma$-proteobacteria & $844 / 852(99 \%)$ \\
\hline LE60-1 & Least Auklet & nape & $\begin{array}{l}\text { Burkholderia sp. } \\
\text { (AY178061) }\end{array}$ & & $\beta$-proteobacteria & $850 / 857(99 \%)$ \\
\hline LE60-4 & Least Auklet & nape & $\begin{array}{l}\text { Burkholderia sp. } \\
\text { (BSU37344) }\end{array}$ & & $\beta$-proteobacteria & $830 / 835(99 \%)$ \\
\hline LE60-8 & Least Auklet & nape & $\begin{array}{l}\text { Burkholderia sp. } \\
\text { (AY178061) }\end{array}$ & & $\beta$-proteobacteria & $837 / 840(99 \%)$ \\
\hline LE63-1 & Least Auklet & nape & $\begin{array}{l}\text { Acinetobacter sp. } \\
(\mathrm{AB} 167206)\end{array}$ & & $\gamma$-proteobacteria & $830 / 832(99 \%)$ \\
\hline LE63-2 & Least Auklet & nape & $\begin{array}{l}\text { Tiedjeia arctica } \\
\text { (DQ107523) }\end{array}$ & & $\gamma$-proteobacteria & $834 / 840(99 \%)$ \\
\hline LE63-6 & Least Auklet & nape & $\begin{array}{l}\text { Janthinobacterium sp. } \\
\text { (AJ846272) }\end{array}$ & & $\beta$-proteobacteria & $847 / 851(99 \%)$ \\
\hline
\end{tabular}


among birds. However, two genera, Psychrobacter and Paenibacillus, were only isolated from Auklet feathers. Members of Psychrobacter are psychrotolerant or psychrophilic and halotolerant and are widely distributed in the Arctic (Cavanagh et al. 1996), while members of Paenibacillus are found in a large number of environments (e.g., the gut of earthworms (Horn et al. 2005) and in industrial wastewater (Meehan et al. 2001)). Thus, the genus Psychrobacter is more likely to be found exclusively on arctic birds. Whether these bacteria play any unique role in the microecology of feathers or have merely been picked up from the environment is an interesting question that will be addressed in future research. In particular, it would be interesting to know if bacteria play a role in production of the tangerine odor of Crested Auklets. Crested Auklets exhibit a characteristic tangerine-like odor that appears to serve social (Hagelin et al. 2003; Jones et al. 2004) and/or anti-parasitic functions (Douglas et al. 2001) while the congeneric Least Auklets do not. The chemical compounds in this odor, simple aldehydes (octanal, 2-decenel) and alcohols (Hagelin et al. 2003), could be derived from bacterial cleavage of more complex fatty acids such as those found in preen gland secretions (Jacob and Ziswiler 1982). Future research will address this possibility.

These data, while limited, add to the rapidly growing field of bird-microbe interactions. By using modern molecular methods to survey arctic seabirds and comparing these results with those from similar studies of passerines, we have shown that certain groups of bacteria (e.g., Pseudomonas, Janthinobacteri$u m$ ) are found on diverse groups of birds and may represent a "normal microflora" for feathers. Others, such as halotolerant Psychrobacter species may be unique to seabirds. The ecology and evolution of these microbes remains a fertile ground for future discovery.

\section{ACKNOWLEDGMENTS}

We thank the people of St. Lawrence Island for their hospitality. This work was partially supported by NSF grant DEB-0077804C to J.L.H. and G.E.H. An anonymous reviewer made useful comments on an earlier draft of the manuscript.

\section{Literature Cited}

Altschul, S. F., T. L. Madden, A. A. Schaffer, J. Zhang, Z. Zhang, W. Miller and D. J. Lipman. 1997. Gapped BLAST and PSI-BLAST: a new generation of protein database search programs. Nucleic Acids Research 25: 3389-3402.

Burtt, E., Jr. and J. Ichida. 1999. Occurrence of featherdegrading Bacilli in the plumage of birds. Auk 116: 364-372.

Cavanagh, J., J. Austin and K. Sanderson. 1996. Novel Psychrobacter species from Antarctic ornithogenic soils. International Journal of Systematic Bacteriology 46: 841-848.

Douglas, H. D., J. E. Co, T. H. Jones and W. E. Conner. 2001. Heteropteran chemical repellents identified in the citrus odor of a seabird (crested auklet: Aethia cristatella): evolutionary convergence in chemical ecology. Naturwissenschaften 88: 330-332.

Goldstein, G., K. R. Flory, B. A. Browne, S. Majid, J. M. Ichida and E. H. Burtt, Jr. 2004. Bacterial degradation of black and white feathers. Auk 121: 656-659.

Hagelin, J. C., I. L. Jones and L. E. L. Rasmussen. 2003. A tangerine-scented social odour in a monogamous seabird. Proceedings of the Royal Society of London Series B-Biological Sciences 270: 1323-1329.

Horn, M. A., J. Ihssen, C. Matthies, A. Schramm, G. Acker and H. L. Drake. 2005. Dechloromonas denitrificans sp. nov., Flavobacterium denitrificans sp. nov., Paenibacillus anaericanus sp. nov. and Paenibacillus terrae strain $\mathrm{MH} 72, \mathrm{~N}_{2} \mathrm{O}$-producing bacteria isolated from the gut of the earthworm Aporrectodea caliginosa. International Journal of Systematic and Evolutionary Microbiology 55: 1255-1265.

Huber, T., G. Faulkner and P. Hugenholtz. 2004. Bellerophon: a program to detect chimeric sequences in multiple sequence alignments. Bioinformatics 20: 2317-2319.

Jacob, J., and V. Ziswiler. 1982. The uropygial gland. In Avian Biology, Vol. 6 (D. S. Farner, J. R. King and K. C. Parkes, Eds.). Academic Press, New York.

Jones, I. L. 1993a. Crested Auklet. In The Birds of North America (A. F. Poole, P. Stettenheim and F. B. Gill, Eds.) American Ornithologists' Union and Academy of Natural Sciences of Philadelphia, Philadelphia.

Jones, I. L. 1993b. Least Auklet. In The Birds of North America (A. F. Poole, P. Stettenheim and F. B. Gill, Eds.) American Ornithologists' Union and Academy of Natural Sciences of Philadelphia, Philadelphia.

Jones, I. L., J. C. Hagelin, H. L. Major and L. E. L. Rasmussen. 2004. An experimental field study of the function of Crested Auklet feather odor. Condor 106: 71-78.

Lucas, F. S., V. Moureau, V. Jourdie and P. Heeb. 2005. Brood size modifications affect plumage bacterial assemblages of European starlings. Molecular Ecology 14: 639-646.

Maidak, B. L., G. J. Olsen, N. Larsen, R. Overbeek, M. J. McCaughey and C. R. Woese. 1997. The RDP (Ribosomal Database Project). Nucleic Acids Research 25: 109-110.

Meehan, C., A. J. Bjourson and G. McMullan. 2001. Paenibacillus azoreducens sp. nov., a synthetic azo dye decolorizing bacterium from industrial wastewater. International Journal of Systematic and Evolutionary Microbiology 51: 1681-1685.

Shawkey, M. D. and G. E. Hill. 2004. Feathers at a fine scale. Auk 141: 652-655. 
Shawkey, M. D., K. L. Mills, C. Dale and G. E. Hill. 2005. Microbial diversity of wild bird feathers revealed through culture-based and culture-independent techniques. Microbial Ecology 50: 40-47.

Shawkey, M. D., S. R. Pillai and G. E. Hill. 2003. Chemical warfare? Effects of uropygial oil on featherdegrading bacteria. Journal of Avian Biology 34: 345-349.
Tanner, M. A., B. M. Goebel, M. A. Dojka and N. R. Pace. 1998. Specific ribosomal DNA sequences from diverse environmental settings correlate with experimental contaminants. Applied and Environmental Microbiology 64: 3110-3113. 